\title{
Fabrication of Perovskite-Type Photovoltaic Devices with Polysilane Hole Transport Layers
}

\author{
Yasuhiro Shirahata1, Takeo Oku1 ${ }^{*}$, Sakiko Fukunishi' ${ }^{2}$, Kazufumi Kohno ${ }^{2}$ \\ ${ }^{1}$ Department of Materials Science, the University of Shiga Prefecture, Shiga, Japan \\ ${ }^{2}$ Frontier Materials Laboratories, Osaka Gas Chemicals Co., Ltd., Osaka, Japan \\ Email: ${ }^{*}$ oku@mat.usp.ac.jp
}

How to cite this paper: Shirahata, Y., Oku, T., Fukunishi, S. and Kohno, K. (2017) Fabrication of Perovskite-Type Photovoltaic Devices with Polysilane Hole Transport Layers. Materials Sciences and Applications, 8, 209-222.

https://doi.org/10.4236/msa.2017.82014

Received: December 19, 2016

Accepted: February 11, 2017

Published: February 14, 2017

Copyright $\odot 2017$ by authors and Scientific Research Publishing Inc. This work is licensed under the Creative Commons Attribution International License (CC BY 4.0).

http://creativecommons.org/licenses/by/4.0/

\begin{abstract}
Perovskite-type photovoltaic devices with polysilane hole transport layers were fabricated by a spin-coating method. In the present work, poly(methyl phenylsilane) (PMPS) and decaphenylcyclopentasilane (DPPS) were used as the hole transport layers. First, structural and optical properties of the PMPS and DPPS films were investigated, and the as-prepared PMPS and DPPS films were amorphous. Optical absorption spectra of the amorphous PMPS and DPPS showed some marked features due to the nature of polysilanes. Then, microstructures, optical and photovoltaic properties of the perovskite-type photovoltaic devices with polysilane hole transport layers were investigated. Current density-voltage characteristics and incident photon to current conversion efficiency of the photovoltaic devices with the polysilane layers showed different photovoltaic performance each other, attributed to molecular structures of the polysilanes and Si content in the present hole transport layers.
\end{abstract}

\section{Keywords}

Polysilane, Hole Transport Layer, Perovskite, Photovoltaic Device

\section{Introduction}

Since the first report of solar cells based on organic-inorganic halide perovskites [1], various perovskite-type solar cells consisting of $\mathrm{ABX}_{3}$ compounds ( $\mathrm{A}=$ $\mathrm{CH}_{3} \mathrm{NH}_{3}, \mathrm{HC}\left(\mathrm{NH}_{3}\right)_{2}$ or $\mathrm{Cs}, \mathrm{B}=\mathrm{Pb}$ or $\mathrm{Sn}, \mathrm{X}=\mathrm{I}, \mathrm{Cl}$ or $\mathrm{Br}$ ) have been extensively studied [2]-[7]. Conversion efficiencies over $20 \%$ have recently been achieved for perovskite-type solar cells [8]-[13]. However, photovoltaic properties of perovskite-type solar cells strongly depend on fabrication process, microstructure and electronic structure of materials. For perovskite-type solar cells, instabilities against humidity, temperature, and continuous light irradiation are also 
crucial issue [14]. Therefore, detailed investigation of perovskite-type solar cells is required to achieve conversion efficiency greater than currently achieved.

2,2',7,7'-tetrakis[ $N, N$-di(p-methoxyphenyl)amino]-9,9'-spirobifluorene (spiro-OMeTAD) is used in perovskite-type solar cells as a hole transport layer because spiro-OMeTAD can yield high conversion efficiency. However, spiroOMeTAD is an expensive organic compound. To circumvent the problem, exploitation of alternate hole transport materials has actually been performed [15] [16] [17] [18].

Polysilanes are promising candidates for the alternate hole transport materials because they are one-dimensional silicon-based materials [19] [20], and can provide good electrical, optical and photovoltaic properties [21] [22] [23] [24]. Very recently, effects of polysilane-doped spiro-OMeTAD hole transport layers were investigated by our group, and the polysilane-doped spiro-OMeTAD hole transport layers were found to increase conversion efficiency of the perovskitetype photovoltaic devices [25]. However, photovoltaic properties of perovskitetype solar cells with polysilanes as hole transport layers have not yet been clarified.

The purpose of the present work is to fabricate of perovskite $\mathrm{CH}_{3} \mathrm{NH}_{3} \mathrm{PbI}_{3}$-based photovoltaic devices with polysilane hole transport layers. In the present study, poly(methyl phenylsilane) (PMPS) and decaphenylcyclopentasilane (DPPS) were used as the hole transport layers, as shown in Figure 1(a) and Figure 1(b), respectively. The photovoltaic devices with the polysilane layers were fabricated by a simple spin-coating method in air atmosphere. Structures, optical and photovoltaic properties of the polysilanes and $\mathrm{CH}_{3} \mathrm{NH}_{3} \mathrm{PbI}_{3}$ were also investigated. The structures and optical properties of the polysilanes and $\mathrm{CH}_{3} \mathrm{NH}_{3} \mathrm{PbI}_{3}$ were investigated by X-ray diffraction (XRD), scanning electron microscopy (SEM), energy dispersive X-ray spectroscopy (EDS) and optical spectroscopy. Besides, the photovoltaic properties of the devices were evaluated by measuring current densityvoltage $(J-V)$ characteristics and incident photon to current conversion efficiency (IPCE). Carrier transport mechanism based on the obtained results was discussed.

(a)

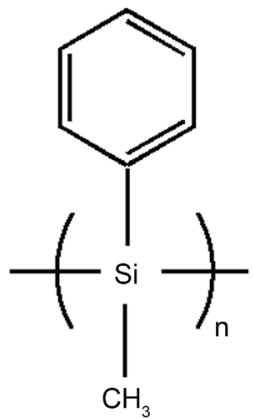

(b)

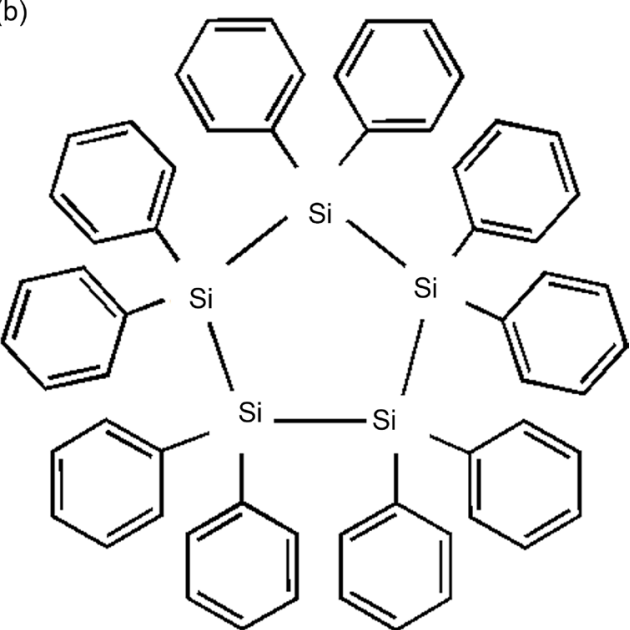

Figure 1. Molecular structures of (a) PMPS and and (b) DPPS. 


\section{Experimental Procedures}

First, polysilane films were prepared on cleaned glass substrates by a spin-coating method [26]. PMPS (Osaka Gas Chemicals, OGSOL SI-10-10, molecular weight (Mw): 16,300, $12 \mathrm{mg}$ ) and DPPS (Osaka Gas Chemicals, OGSOL SI-3010, Mw: $945.11,12 \mathrm{mg}$ ) powders were separately dissolved in $o$-dichloro-benzene (Wako Pure Chemical Industries, $500 \mu \mathrm{L}$ ). Triphenylborate solution (Sigma-Aldrich, $25 \mu \mathrm{L}$ ) was added into the polysilane solutions as a $p$-type dopant [26]. Non-doped and boron (B)-doped polysilane solutions were stirred at room temperature. The polysilane solutions were dropped on the glass substrates, and spun by a spin coater (Mikasa, MS-A 100) at $1500 \mathrm{rpm}$ for $30 \mathrm{~s}$. This process was repeated until the desired thickness. Then, $\mathrm{CH}_{3} \mathrm{NH}_{3} \mathrm{PbI}_{3}$-based photovoltaic devices with polysilane hole transport layers were also fabricated to investigate photovoltaic properties of the polysilanes. The detailed fabrication process was described in our previous reports [18] [25] [27] [28] [29] [30], except for those of $\mathrm{CH}_{3} \mathrm{NH}_{3} \mathrm{PbI}_{3}$ and polysilane layers. In the present work, 0.15 and $0.30 \mathrm{M}$ compact $\mathrm{TiO}_{x}$ precursor solutions were prepared from titanium diisopropoxide bis(acetyl-acetonate) (Sigma-Aldrich, $0.055 \mathrm{~mL}$ and $0.11 \mathrm{~mL}$ ) and 1-butanol (Nacalai Tesque, $1 \mathrm{~mL}$ ). The $0.15 \mathrm{M} \mathrm{TiO}_{x}$ precursor layer was spin-coated onto cleaned fluorine (F)-doped tin oxide (FTO) substrate by the spin coater at 3000 rpm for 30 s. After that, the $\mathrm{TiO}_{x}$ was dried on a hot plate (As One, ND-1) at $125^{\circ} \mathrm{C}$ for $5 \mathrm{~min}$. Likewise, the $0.30 \mathrm{M} \mathrm{TiO}_{x}$ precursor layer was spin-coated onto the $0.15 \mathrm{M} \mathrm{TiO}_{x}$ layer at $3000 \mathrm{rpm}$ for $30 \mathrm{~s}$, and dried at $125^{\circ} \mathrm{C}$ for $5 \mathrm{~min}$. This process was repeated twice. Finally, the $\mathrm{TiO}_{x}$ layer was annealed in an electric furnace (as one, SMF-1) at $500^{\circ} \mathrm{C}$ for $30 \mathrm{~min}$. After cooling to room temperature, mesoporous $\mathrm{TiO}_{2}$ layer was spin-coated onto the compact $\mathrm{TiO}_{2}$ layer at $5000 \mathrm{rpm}$ for $30 \mathrm{~s}$, and was dried on the hot plate at $125^{\circ} \mathrm{C}$ for $5 \mathrm{~min}$. The mesoporous $\mathrm{TiO}_{2}$ layer was sintered in the electric furnace at $500^{\circ} \mathrm{C}$ for $30 \mathrm{~min}$. Prior to spin-coating of the mesoporous $\mathrm{TiO}_{2}$, the $\mathrm{TiO}_{2}$ paste was prepared by dispersing $\mathrm{TiO}_{2}$ powder (Aerosil, P-25) in ultrapure water. Poly(ethylene glycol) (Nacalai Tesque, averaged molecular number: 20,000, $10 \mathrm{mg}$ ), acetylacetone (Wako Pure Chemical Industries, $10 \mu \mathrm{L}$ ) and a surfactant (Sigma-Aldrich, Triton $\mathrm{X}-100,5 \mu \mathrm{L}$ ) were added in the $\mathrm{TiO}_{2}$ paste. The paste was stirred for $30 \mathrm{~min}$, and was left overnight without stirring. For preparation of $\mathrm{CH}_{3} \mathrm{NH}_{3} \mathrm{PbI}_{3}$ layers, a combination of a one-step solution deposition method [18] [25] [27] [28] [29] [30] [31] and hot air flow-assisted spin-coating technique [17] [32] was adopted in the present work. The preparation process of the $\mathrm{CH}_{3} \mathrm{NH}_{3} \mathrm{PbI}_{3}$ layers were as follows: $\mathrm{CH}_{3} \mathrm{NH}_{3} \mathrm{I}$ (Showa Chemical, $99.8 \mathrm{mg}$ ) and $\mathrm{PbI}_{2}$ (Sigma-Aldrich, 289.3 $\mathrm{mg}$ ) were dissolved in a mixed solvent consisting of $\gamma$-butyrolactone (Wako Pure Chemical Industries, $300 \mu \mathrm{L}$ ) and $N, N$-dimethylformamide (DMF) (Nacalai Tesque, $200 \mu \mathrm{L}$ ) [33]. The molar ratio of the solutes was 1:1. The $\mathrm{CH}_{3} \mathrm{NH}_{3} \mathrm{PbI}_{3}$ solution was stirred at $60^{\circ} \mathrm{C}$ over $2 \mathrm{~h}$. Prior to spin-coating, the solution was filtered using a $0.20 \mu \mathrm{m}$ poly(vinylidene difluoride) syringe filter unit (Advantec, Dismic $13 \mathrm{HP}$ ). Moreover, the substrate was kept at $50^{\circ} \mathrm{C}$ by a heating gun, checked by a thermometer. The $\mathrm{CH}_{3} \mathrm{NH}_{3} \mathrm{PbI}_{3}$ solution was immersed into the 
mesoporous $\mathrm{TiO}_{2}$ layer, and was spun at $2000 \mathrm{rpm}$ for $60 \mathrm{~s}$. During the spincoating, hot air from the heating gun was continuously flown. The spin-coated $\mathrm{CH}_{3} \mathrm{NH}_{3} \mathrm{PbI}_{3}$ layer was then annealed on the hot plate at $100^{\circ} \mathrm{C}$ for $1 \mathrm{~min}$. After that, B-doped PMPS (PMPS:B) and DPPS (DPPS:B) solutions were dropped onto the $\mathrm{CH}_{3} \mathrm{NH}_{3} \mathrm{PbI}_{3}$ layers, and were spun at $1500 \mathrm{rpm}$ for $30 \mathrm{~s}$ without hot air flow. The spin-coating process was repeated twice. Finally, gold ( $\mathrm{Au}$ ) electrodes were deposited onto the polysilane layers by a vacuum evaporation system (Sanyu Electron Co., Ltd., SVC-700TM/SVC-700-2). The present photovoltaic devices are denoted as $\mathrm{FTO} / \mathrm{TiO}_{2} / \mathrm{CH}_{3} \mathrm{NH}_{3} \mathrm{PbI}_{3} / \mathrm{PMPS}: \mathrm{B}$ or DPPS:B/Au.

The PMPS, PMPS:B, DPPS and DPPS:B films were characterized by an Xray diffractometer (Bruker Corporation, D2 PHASER). Optical absorption spectra of the polysilane films were collected by an ultraviolet-visible-near inferred (UV-VIS-NIR) spectrometer (Jasco Corporation, V-770). The $\mathrm{CH}_{3} \mathrm{NH}_{3} \mathrm{PbI}_{3}$ layers in the $\mathrm{FTO} / \mathrm{TiO}_{2} / \mathrm{CH}_{3} \mathrm{NH}_{3} \mathrm{PbI}_{3} / \mathrm{PMPS}: \mathrm{B} / \mathrm{Au}$ and $\mathrm{FTO} / \mathrm{TiO}_{2} / \mathrm{CH}_{3} \mathrm{NH}_{3} \mathrm{PbI}_{3} /$ DPPS:B/Au devices were also evaluated by XRD and SEM (Jeol Ltd., JSM6010PLUS/LA) attached with an EDS detector. The optical absorption spectra of the $\mathrm{CH}_{3} \mathrm{NH}_{3} \mathrm{PbI}_{3}$ in the photovoltaic devices with the polysilane hole transport layers were collected using the UV-VIS-NIR spectrometer. The $J$ - $V$ characteristics of the $\mathrm{FTO} / \mathrm{TiO}_{2} / \mathrm{CH}_{3} \mathrm{NH}_{3} \mathrm{PbI}_{3} / \mathrm{PMPS}: \mathrm{B} / \mathrm{Au}$ and $\mathrm{FTO} / \mathrm{TiO}_{2} / \mathrm{CH}_{3} \mathrm{NH}_{3} \mathrm{PbI}_{3} /$ DPPS:B/Au were measured using a potentiostat (Hokuto Denko Corporation, HSV-110) under simulated AM $1.5\left(100 \mathrm{~mW} \cdot \mathrm{cm}^{-2}\right)$ irradiation conditions. The light was irradiated from the bottom side of FTO-coated glass substrate using a solar simulator (San-Ei Electric Co., Ltd., XES-301S). Effective area of the devices was $0.090 \mathrm{~cm}^{2}$. IPCE spectra of the devices were also collected using an IPCE measurement system (Enli Technology Co., Ltd., QE-R). All measurements were carried out at room temperature.

\section{Results and Discussion}

Figure 2(a) shows XRD patterns of as-prepared PMPS, PMPS:B, DPPS and DPPS:B films. Broad peaks around $24^{\circ}$ were the signals from the sample holder. All the as-prepared films were amorphous. Figure 2(b) exhibited heat-treated PMPS, PMPS:B, DPPS and DPPS:B films. The heat treatment was carried out at $100^{\circ} \mathrm{C}$ for $10 \mathrm{~min}$. The DPPS and DPPS:B films were crystallized, as shown in Figure 2 (b), which agreed with our previous report [26]. Compared with the XRD pattern of heat-treated DPPS film, a peak shift to lower diffraction angle was observed for the heat-treated DPPS:B one, suggesting a structural change of DPPS by $B$ doping and heat trearment. On the other hand, the PMPS and PMPS:B films were not crystallized. In the present work, non-heated PMPS:B and DPPS:B hole transport layers were prepared on the $\mathrm{CH}_{3} \mathrm{NH}_{3} \mathrm{PbI}_{3}$-based photovoltaic devices.

Figure 3(a) and Figure 3(b) show optical absorption spectra of the as-prepared PMPS, PMPS:B, DPPS and DPPS:B films. Absorption intensities of PMPS and PMPS:B films shown in Figure 3(a) were almost same regardless of B doping. Some marked features were observed at 223, 243, 340 and $435 \mathrm{~nm}$ for PMPS and PMPS:B films. The features at 223, 243 and $340 \mathrm{~nm}$ can be assigned 
(a)

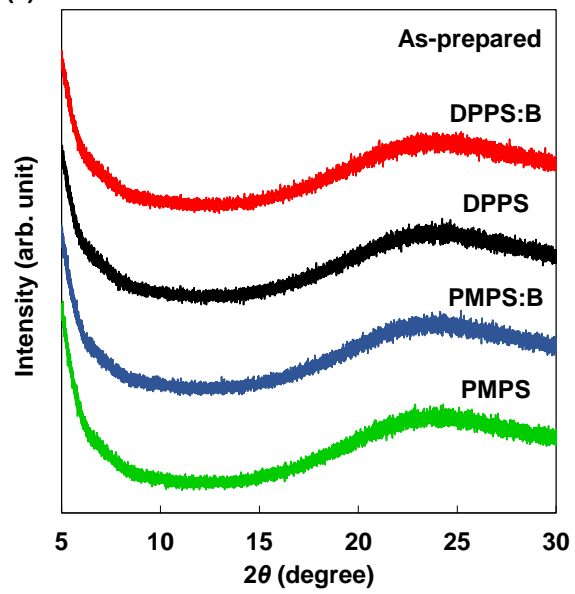

(b)

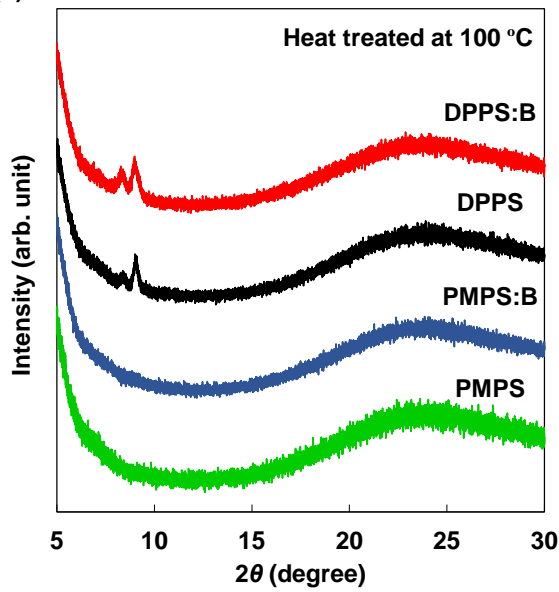

Figure 2. XRD patterns of (a) as-prepared and (b) heat-treated polysilanes prepared on glass substrates.

(a)

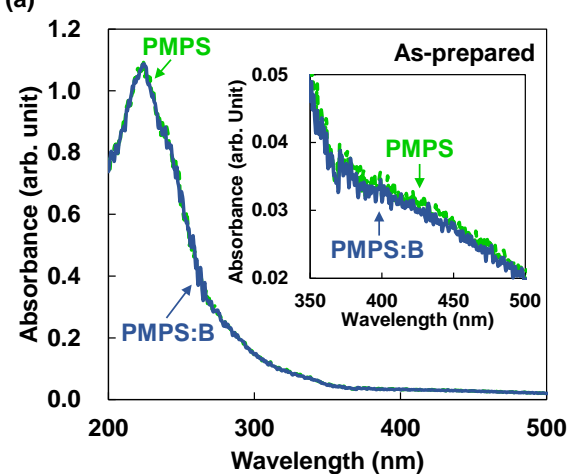

(b)

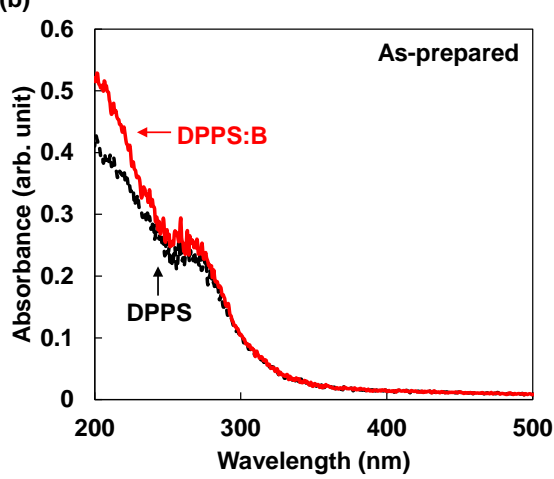

Figure 3. Optical absorption spectra of (a) PMPS (dashed green line) and PMPS:B (solid blue line) films, and (b) DPPS (dashed black line) and DPPS:B (solid red line) films. Inset in (a) is enlarged optical absorption spectra of PMPS and PMPS:B films.

to Si-C bond-related transition [34], $\pi-\pi^{*}$ transition of phenyl group [35] and $\sigma-\sigma^{\star}$ transition of polysilane chain [35], respectively. The feature at $435 \mathrm{~nm}$ shown in inset in Figure 3(a) was derived from charge transfer excitation [35]. In contrast, absorption intensity of DPPS:B film shown in Figure 3(b) was larger than that of DPPS one, which was presumably due to B doping. A marked feature was observed at $272 \mathrm{~nm}$ for the DPPS and DPPS:B films, which would be assigned to $\sigma-\sigma^{\star}$ transition. From the edges of the $\sigma-\sigma^{\star}$ transitions, energy gaps of the PMPS, PMPS:B, DPPS and DPPS:B films were estimated to be $3.49,3.49$, and 3.68 and $3.66 \mathrm{eV}$, respectively.

XRD patterns of $\mathrm{FTO} / \mathrm{TiO}_{2} / \mathrm{CH}_{3} \mathrm{NH}_{3} \mathrm{PbI}_{3} / \mathrm{PMPS}: \mathrm{B} / \mathrm{Au}$ and $\mathrm{FTO} / \mathrm{TiO}_{2} / \mathrm{CH}_{3} \mathrm{NH}_{3} \mathrm{PbI}_{3} /$ DPPS:B/Au photovoltaic devices are shown in Figure 4. The diffraction peaks corresponding to $\mathrm{CH}_{3} \mathrm{NH}_{3} \mathrm{PbI}_{3}$ with a cubic system ( $\mathrm{Pm} \overline{3} \mathrm{~m}$ ) were observed. Some sharp diffraction peaks of $\mathrm{PbI}_{2}$ were simultaneously observed at $12.5^{\circ}$ and $25.9^{\circ}$, assumed that phase separation of $\mathrm{PbI}_{2}$ from $\mathrm{CH}_{3} \mathrm{NH}_{3} \mathrm{PbI}_{3}$ occurred [27]. From the XRD patterns in Figure 4, lattice constants (a) and unit cell volumes $(V)$ of the $\mathrm{CH}_{3} \mathrm{NH}_{3} \mathrm{PbI}_{3}$ were estimated, as presented in Table 1 . The $a$ and $V$ values of the 
$\mathrm{CH}_{3} \mathrm{NH}_{3} \mathrm{PbI}_{3}$ in the two devices were larger than those of our previous reports [25] [27] [28] [29] because these structural parameters strongly depend on growth conditions. Crystallite sizes $(D)$ of the $\mathrm{CH}_{3} \mathrm{NH}_{3} \mathrm{PbI}_{3}$ were estimated using Scherrer's equation: $D=0.9 \lambda / \beta \cos \theta$. Here, $\lambda, \beta$ and $\theta$ are the X-ray wavelength $(0.154184$ $\mathrm{nm})$, full width at half maximum of diffraction peaks and Bragg angle, respectively. The $D$ values presented in Table 1 were almost same regardless of difference in hole transport materials.

A SEM image of the $\mathrm{FTO} / \mathrm{TiO}_{2} / \mathrm{CH}_{3} \mathrm{NH}_{3} \mathrm{PbI}_{3} / \mathrm{PMPS}: \mathrm{B} / \mathrm{Au}$ device is shown in Figure 5(a). Many diamond-, cross- and cubic-shaped grains with sizes of 15 $30 \mathrm{~nm}$ were observed. Figure 5(b) represents an EDS spectrum for the $\mathrm{FTO} / \mathrm{TiO}_{2} / \mathrm{CH}_{3} \mathrm{NH}_{3} \mathrm{PbI}_{3} / \mathrm{PMPS} \mathrm{B} / \mathrm{Au}$ device. It was confirmed that $\mathrm{Pb}, \mathrm{I}, \mathrm{Si}$ and $\mathrm{B}$ were contained in the device. Ti and $\mathrm{Sn}$ respectively derived from $\mathrm{TiO}_{2}$ and FTO were also detected. Elemental mapping images of $\mathrm{Pb}, \mathrm{I}, \mathrm{Si}$ and $\mathrm{B}$ in the device collected by EDS detector are shown in Figures $5(\mathrm{c})-(\mathrm{f})$, respectively. The contents of $\mathrm{Pb}, \mathrm{I}, \mathrm{Si}$ and $\mathrm{B}$ are presented in Table 2. The elemental mapping images clarified that the grains shown in Figure 5 (a) were $\mathrm{CH}_{3} \mathrm{NH}_{3} \mathrm{PbI}_{3}$ because distribution of $\mathrm{Pb}$ and I atoms corresponded to the grains. Simultaneously, it was confirmed that $\mathrm{Si}$ and B atoms in the PMPS:B were distributed all over the $\mathrm{CH}_{3} \mathrm{NH}_{3} \mathrm{PbI}_{3}$ layer. However, content of $\mathrm{B}$ was below detection limit (BDL).

Likewise, a SEM image of the $\mathrm{FTO} / \mathrm{TiO}_{2} / \mathrm{CH}_{3} \mathrm{NH}_{3} \mathrm{PbI}_{3} / \mathrm{DPPS}: \mathrm{B} / \mathrm{Au}$ device is shown in Figure 6(a). Many cross-shaped grains with sizes of 20 - $40 \mathrm{~nm}$ were observed, considered that PMPS:B and DPPS:B affected surface morphology of

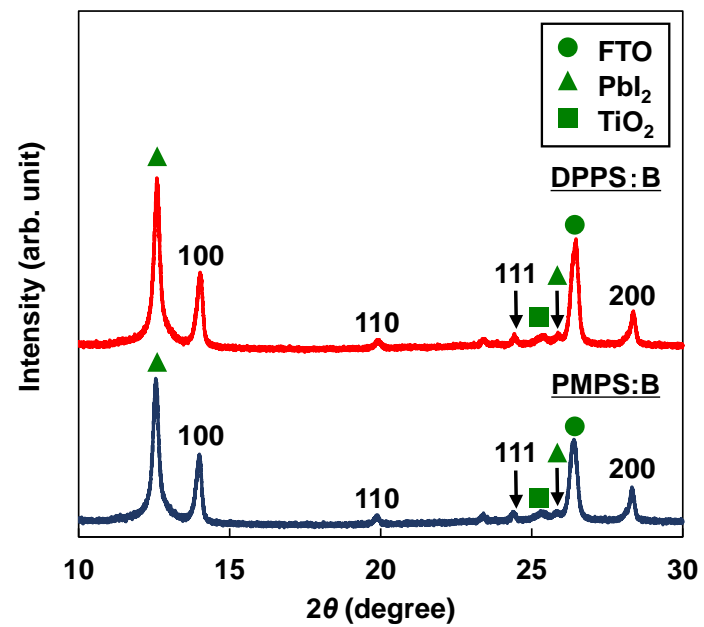

Figure 4. XRD patterns of $\mathrm{FTO} / \mathrm{TiO}_{2} / \mathrm{CH}_{3} \mathrm{NH}_{3} \mathrm{PbI}_{3} / \mathrm{PMPS}: \mathrm{B} / \mathrm{Au}$ and $\mathrm{FTO} / \mathrm{TiO}_{2} / \mathrm{CH}_{3} \mathrm{NH}_{3} \mathrm{PbI}_{3} / \mathrm{DPPS}: \mathrm{B} / \mathrm{Au}$ photovoltaic devices.

Table 1. Lattice constants (a), volumes ( $V$ ) and crystallite sizes $(D)$ of $\mathrm{CH}_{3} \mathrm{NH}_{3} \mathrm{PbI}_{3}$ in $\mathrm{FTO} / \mathrm{TiO}_{2} / \mathrm{CH}_{3} \mathrm{NH}_{3} \mathrm{PbI}_{3} / \mathrm{DPPS}: \mathrm{B} / \mathrm{Au}$ and $\mathrm{FTO} / \mathrm{TiO}_{2} / \mathrm{CH}_{3} \mathrm{NH}_{3} \mathrm{PbI}_{3} / \mathrm{PMPS}: \mathrm{B} / \mathrm{Au}$ photovoltaic devices.

\begin{tabular}{cccc}
\hline Hole transport layer & $a / \mathrm{nm}$ & $V / \mathrm{nm}^{3}$ & $D / \mathrm{nm}$ \\
\hline PMPS:B & $0.6301(3)$ & $0.2500(7)$ & $104 \pm 14$ \\
DPPS:B & $0.6293(3)$ & $0.2492(5)$ & $102 \pm 13$ \\
\hline
\end{tabular}



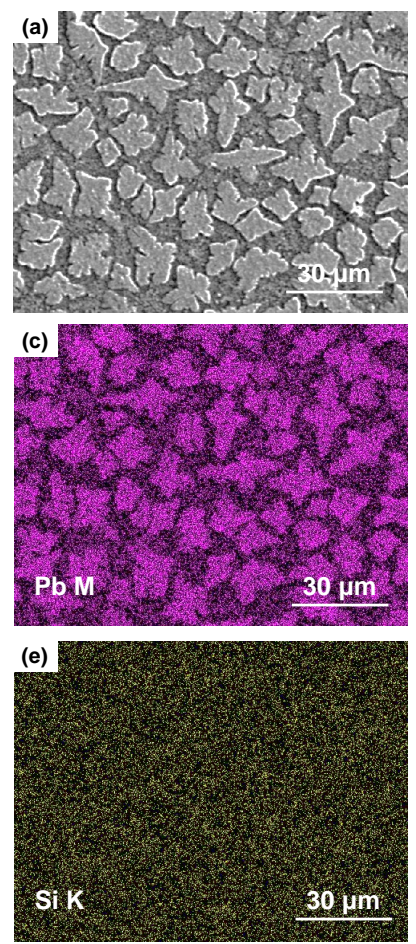
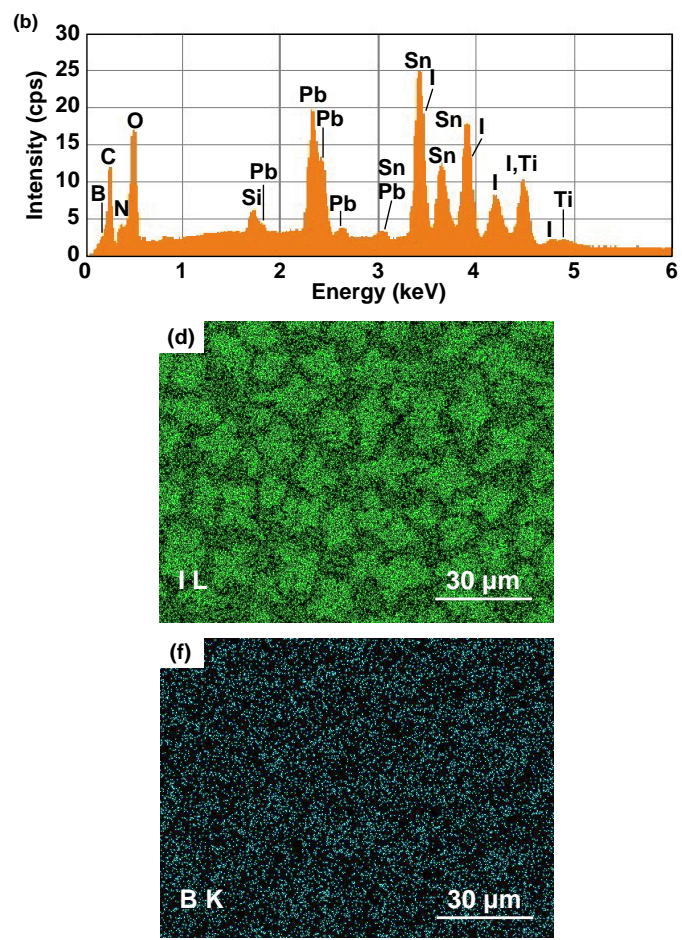

Figure 5. (a) SEM image of $\mathrm{CH}_{3} \mathrm{NH}_{3} \mathrm{PbI}_{3}$ surface in $\mathrm{FTO} / \mathrm{TiO}_{2} / \mathrm{CH}_{3} \mathrm{NH}_{3} \mathrm{PbI}_{3} / \mathrm{PMPS}: \mathrm{B} / \mathrm{Au}$ photovoltaic device. (b) EDS spectrum for $\mathrm{FTO} / \mathrm{TiO}_{2} / \mathrm{CH}_{3} \mathrm{NH}_{3} \mathrm{PbI}_{3} / \mathrm{PMPS}: \mathrm{B} / \mathrm{Au}$ device. (c)-(f) Elemental mapping images of (b) Pb M line, (c) I L line, (d) Si K line and (d) B K line.

$\mathrm{CH}_{3} \mathrm{NH}_{3} \mathrm{PbI}_{3}$ because of their different molecular structures. An EDS spectrum for the $\mathrm{FTO} / \mathrm{TiO}_{2} / \mathrm{CH}_{3} \mathrm{NH}_{3} \mathrm{PbI}_{3} / \mathrm{DPPS}: \mathrm{B} / \mathrm{Au}$ device is shown in Figure $6(\mathrm{~b}) . \mathrm{Pb}, \mathrm{I}, \mathrm{Si}$ and $\mathrm{B}$ atoms were confirmed as well as the $\mathrm{FTO} / \mathrm{TiO}_{2} / \mathrm{CH}_{3} \mathrm{NH}_{3} \mathrm{PbI}_{3} / \mathrm{PMPS}: \mathrm{B} / \mathrm{Au}$ device. Elemental mapping images of $\mathrm{Pb}, \mathrm{I}, \mathrm{Si}$ and $\mathrm{B}$ in the device are shown in Figures 6(c)-(f). It is considered that the cross-shaped grains corresponded to $\mathrm{CH}_{3} \mathrm{NH}_{3} \mathrm{PbI}_{3}$. The contents of $\mathrm{Pb}, \mathrm{I}, \mathrm{Si}$ and $\mathrm{B}$ are presented in Table 2. The content of $\mathrm{Si}$ in the $\mathrm{FTO} / \mathrm{TiO}_{2} / \mathrm{CH}_{3} \mathrm{NH}_{3} \mathrm{PbI}_{3} / \mathrm{DPPS}: \mathrm{B} / \mathrm{Au}$ device was smaller than that in the $\mathrm{FTO} / \mathrm{TiO}_{2} / \mathrm{CH}_{3} \mathrm{NH}_{3} \mathrm{PbI}_{3} / \mathrm{PMPS}: \mathrm{B} / \mathrm{Au}$ one. The difference would be attributed to molecular weight of the polysilanes.

Optical absorption spectra of the $\mathrm{FTO} / \mathrm{TiO}_{2} / \mathrm{CH}_{3} \mathrm{NH}_{3} \mathrm{PbI}_{3} / \mathrm{PMPS}: \mathrm{B} / \mathrm{Au}$ and $\mathrm{FTO} / \mathrm{TiO}_{2} / \mathrm{CH}_{3} \mathrm{NH}_{3} \mathrm{PbI}_{3} / \mathrm{DPPS}: \mathrm{B} / \mathrm{Au}$ photovoltaic devices are shown in Figure 7 (a). Broad absorption spectra were obtained in the range of $400-780 \mathrm{~nm}$. Two peak structures at 415 and $500 \mathrm{~nm}$ would be derived from $\mathrm{TiO}_{2}$ and $\mathrm{PbI}_{2}$, respectively [36] [37]. From the optical absorption spectra, energy gaps of the $\mathrm{CH}_{3} \mathrm{NH}_{3} \mathrm{PbI}_{3}$ layers in the devices were estimated by Tauc's formula: $(h v \alpha)^{n}=$ $A\left(h v-E_{g}\right)$, where $h, v, \alpha, A, E_{g}$ and $n$ are the Plank constant, light frequency, optical coefficient, proportional constant, energy gap, and power index which depends on the nature of the transition, respectively. In the present study, $n=2$ was used for the $\mathrm{CH}_{3} \mathrm{NH}_{3} \mathrm{PbI}_{3}$ because $\mathrm{CH}_{3} \mathrm{NH}_{3} \mathrm{PbI}_{3}$ is a direct transition semiconductor [38]. As shown in Figure 7(b), the $E_{g}$ of the $\mathrm{CH}_{3} \mathrm{NH}_{3} \mathrm{PbI}_{3}$ in the two devices were $1.59 \mathrm{eV}$, comparable with reported $E_{g}$ of $\mathrm{CH}_{3} \mathrm{NH}_{3} \mathrm{PbI}_{3}$ prepared with a mixed solvent consisting of $\gamma$-butyrolactone and DMF [33]. However, there was no peak 

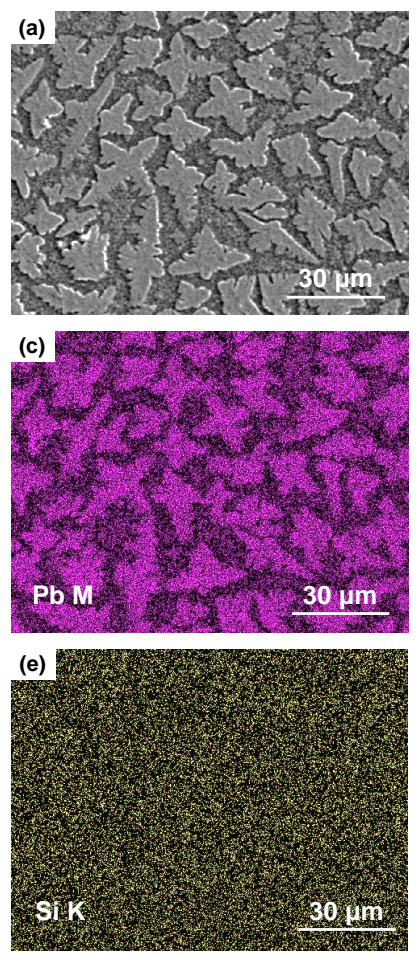
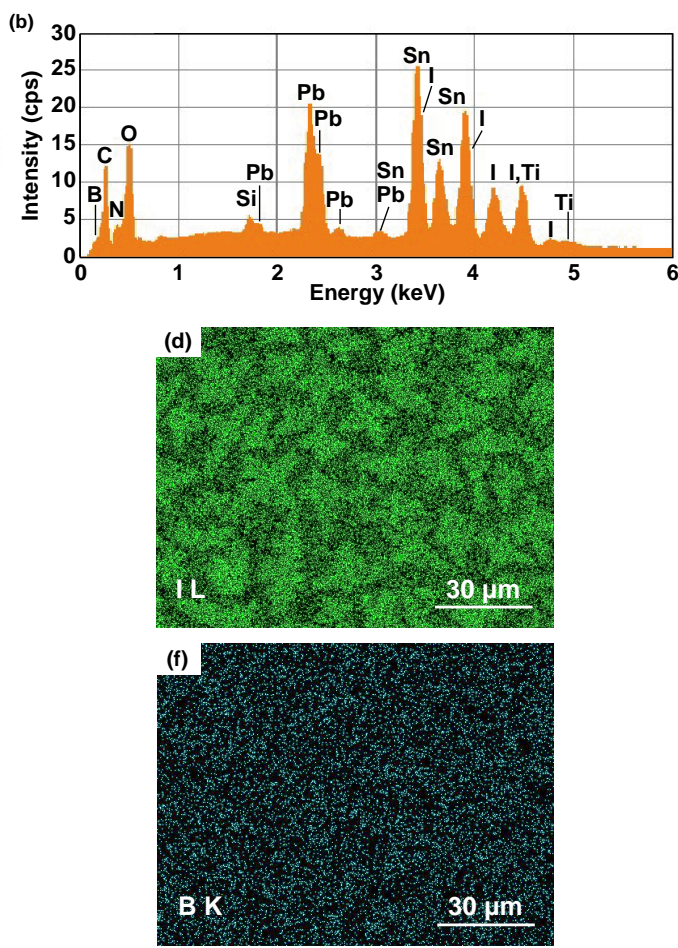

Figure 6. (a) SEM image of $\mathrm{CH}_{3} \mathrm{NH}_{3} \mathrm{PbI}_{3}$ surface in $\mathrm{FTO} / \mathrm{TiO}_{2} / \mathrm{CH}_{3} \mathrm{NH}_{3} \mathrm{PbI}_{3} / \mathrm{DPPS}: \mathrm{B} / \mathrm{Au}$ photovoltaic device. (b) EDS spectrum for $\mathrm{FTO} / \mathrm{TiO}_{2} / \mathrm{CH}_{3} \mathrm{NH}_{3} \mathrm{PbI}_{3} / \mathrm{DPPS}: \mathrm{B} / \mathrm{Au}$ device. (c)-(f) Elemental image mapping images of (b) $\mathrm{Pb} \mathrm{M}$ line, (c) I L line, (d) Si K line and (d) $\mathrm{B} \mathrm{K}$ line.

Table 2. Compsitions of $\mathrm{FTO} / \mathrm{TiO}_{2} / \mathrm{CH}_{3} \mathrm{NH}_{3} \mathrm{PbI}_{3} / \mathrm{DPPS}: \mathrm{B} / \mathrm{Au}$ photovoltaic devices. BDL means below detection limit.

\begin{tabular}{ccccc}
\hline & \multicolumn{4}{c}{ Composition/at \% } \\
Hole transport layer & $\mathrm{Pb}$ & $\mathrm{I}$ & $\mathrm{Si}$ & $\mathrm{B}$ \\
\cline { 2 - 4 } & 36.4 & 56.2 & 7.4 & $\mathrm{BDL}$ \\
PMPS:B & 37.1 & 58.2 & 4.7 & BDL \\
\hline
\end{tabular}

(a)

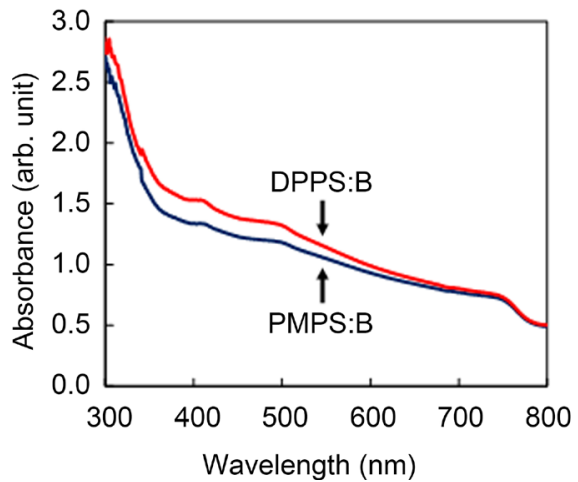

(b)

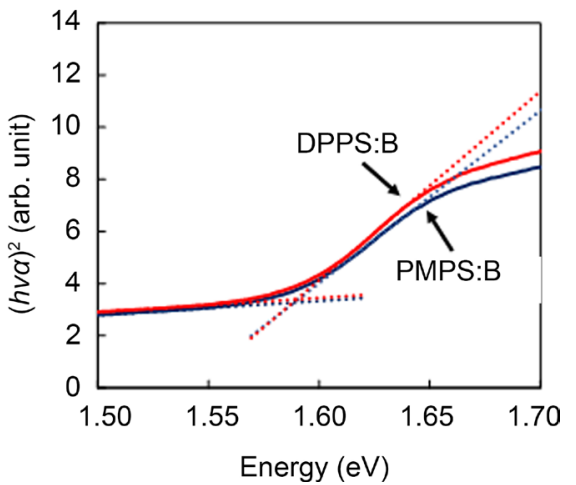

Figure 7. (a) Optical absorption spectra of $\mathrm{FTO} / \mathrm{TiO}_{2} / \mathrm{CH}_{3} \mathrm{NH}_{3} \mathrm{PbI}_{3} / \mathrm{PMPS}: \mathrm{B} / \mathrm{Au}$ and FTO/TiO $/ \mathrm{CH}_{3} \mathrm{NH}_{3} \mathrm{PbI}_{3} / \mathrm{DPPS}: \mathrm{B} / \mathrm{Au}$ photovoltaic devices. (b) Tauc plots of $\mathrm{FTO} / \mathrm{TiO}_{2} /$ $\mathrm{CH}_{3} \mathrm{NH}_{3} \mathrm{PbI}_{3} / \mathrm{PMPS}: \mathrm{B} / \mathrm{Au}$ and $\mathrm{FTO} / \mathrm{TiO}_{2} / \mathrm{CH}_{3} \mathrm{NH}_{3} \mathrm{PbI}_{3} / \mathrm{DPPS}: \mathrm{B} / \mathrm{Au}$ photovoltaic devices. 
related to DPPS:B and PMPS:B layers, presumably due to their film thickness.

Figure 8(a) shows $J-V$ characteristics of the $\mathrm{FTO} / \mathrm{TiO}_{2} / \mathrm{CH}_{3} \mathrm{NH}_{3} \mathrm{PbI} / \mathrm{PMPS}: \mathrm{B} / \mathrm{Au}$ and $\mathrm{FTO} / \mathrm{TiO}_{2} / \mathrm{CH}_{3} \mathrm{NH}_{3} \mathrm{PbI}_{3} / \mathrm{DPPS}: \mathrm{B} / \mathrm{Au}$ photovoltaic devices under light irradiation. The photovoltaic devices showed clear rectifying behavior with short-circuit current density $\left(J_{s c}\right)$ and open circuit voltage $\left(V_{o c}\right)$. A $J_{s c}$ of $4.56 \mathrm{~mA} \cdot \mathrm{cm}^{-2}, V_{o c}$ of $0.610 \mathrm{~V}$, fill factor (FF) of 0.551 and conversion efficiency $(\eta)$ of $1.53 \%$ were obtained for the $\mathrm{FTO} / \mathrm{TiO}_{2} / \mathrm{CH}_{3} \mathrm{NH}_{3} \mathrm{PbI}_{3} / \mathrm{PMPS}: \mathrm{B} / \mathrm{Au}$ device. Compared with the device with PMPS:B hole transport layer, on the other hand, photovoltaic properties of the $\mathrm{FTO} / \mathrm{TiO}_{2} / \mathrm{CH}_{3} \mathrm{NH}_{3} \mathrm{PbI}_{3} / \mathrm{DPPS}: \mathrm{B} / \mathrm{Au}$ device were improved. From the $J-V$ characteristics of the $\mathrm{FTO} / \mathrm{TiO}_{2} / \mathrm{CH}_{3} \mathrm{NH}_{3} \mathrm{PbI}_{3} / \mathrm{DPPS}: \mathrm{B} / \mathrm{Au}$ device shown in Figure 8(a), a $J_{s c}$ of $6.96 \mathrm{~mA} \mathrm{~cm}{ }^{-2}, V_{o c}$ of $0.578 \mathrm{~V}, \mathrm{FF}$ of 0.454 and $\eta$ of $1.83 \%$ were obtained. These difference were attributed to molecular structures of the polysilanes and $\mathrm{Si}$ content in the hole transport layers. In fact, improvement of conversion efficiency on perovskite-based photovoltaic devices with different types of polysilane-doped spiro-OMeTAD hole transport layers were recently reported, and photovoltaic properties of the perovskite-based photovoltaic devices depended on the contents of $\mathrm{Si}$ [25]. The $\eta$, however, were still lower than the perovskitebased solar devices with spiro-OMeTAD, phthalocyanine, and copper thiocyanate hole transport materials [15] [16] [17] [18]. IPCE spectra of the $\mathrm{FTO} / \mathrm{TiO}_{2} /$ $\mathrm{CH}_{3} \mathrm{NH}_{3} \mathrm{PbI}_{3} / \mathrm{PMPS}: \mathrm{B} / \mathrm{Au}$ and $\mathrm{FTO} / \mathrm{TiO}_{2} / \mathrm{CH}_{3} \mathrm{NH}_{3} \mathrm{PbI}_{3} / \mathrm{DPPS}: \mathrm{B} / \mathrm{Au}$ photovoltaic devices are shown in Figure 8(b). Broad IPCE spectra were obtained in the wavelength range from 300 and $800 \mathrm{~nm}$, indicating that exciton and/or free charge generation occurred in the $\mathrm{CH}_{3} \mathrm{NH}_{3} \mathrm{PbI}_{3}$ layer. In addition to these results, holes in the $\mathrm{CH}_{3} \mathrm{NH}_{3} \mathrm{PbI}_{3}$ were effectively transported through the polysilane layers because intensity of the IPCE spectrum is proportional to the $\eta$, suggesting that the DPPS:B layer had a good mobility compared with the PMPS:B one. Integrated $J_{s c}$ shown in Figure 8(b) agreed with the $J_{s c}$ obtained from the $J$ - $V$ characteristics in Figure 8(a). Effective energy gaps $\left(E_{g}^{*}\right)$ can also be determined [39]. By extrapolating the linear part of the graph to meet $\left(h v^{*} \mathrm{IPCE}\right)^{2}=0$, the $E_{g}^{*}$ of the two devices were estimated.

(a)

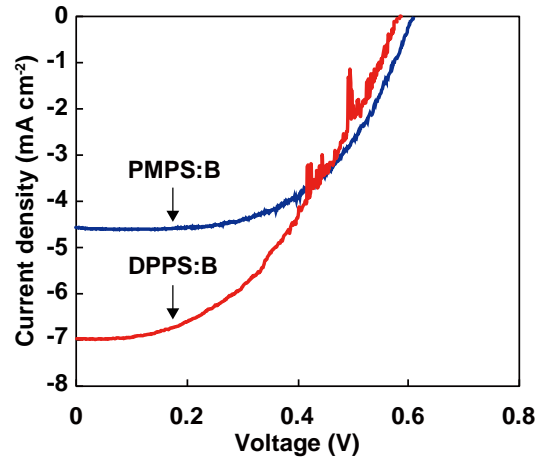

(b)

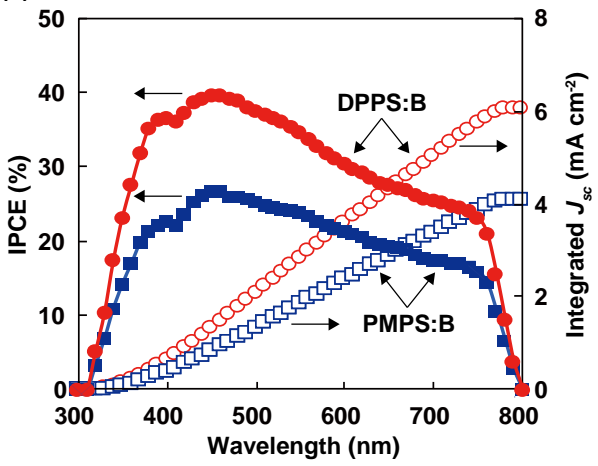

Figure 8. (a) $J-V$ curves of $\mathrm{FTO} / \mathrm{TiO}_{2} / \mathrm{CH}_{3} \mathrm{NH}_{3} \mathrm{PbI}_{3} / \mathrm{PMPS}: \mathrm{B} / \mathrm{Au}$ and $\mathrm{FTO} / \mathrm{TiO}_{2} /$ $\mathrm{CH}_{3} \mathrm{NH}_{3} \mathrm{PbI}_{3} / \mathrm{DPPS}: \mathrm{B} / \mathrm{Au}$ photovoltaic devices. (b) IPCE spectra and integrated $J_{s c}$ of FTO/TiO $/ 2 \mathrm{CH}_{3} \mathrm{NH}_{3} \mathrm{PbI}_{3} / \mathrm{PMPS}: \mathrm{B} / \mathrm{Au}$ and $\mathrm{FTO} / \mathrm{TiO}_{2} / \mathrm{CH}_{3} \mathrm{NH}_{3} \mathrm{PbI}_{3} / \mathrm{DPPS}: \mathrm{B} / \mathrm{Au}$ photovoltaic devices. 
to be $1.57 \mathrm{eV}$ (not shown), which agreed with the $E_{g}$ shown in Figure 7(b). These values indicate that the spectral mismatches between AM 1.5 solar simulator, IPCE measurement system and UV-VIS-NIR spectrophotometer were small.

To explain charge transport, energy band diagrams of the FTO/ $\mathrm{TiO}_{2} /$ $\mathrm{CH}_{3} \mathrm{NH}_{3} \mathrm{PbI}_{3} / \mathrm{PMPS}: \mathrm{B} / \mathrm{Au}$ and $\mathrm{FTO} / \mathrm{TiO}_{2} / \mathrm{CH}_{3} \mathrm{NH}_{3} \mathrm{PbI}_{3} / \mathrm{DPPS}: \mathrm{B} / \mathrm{Au}$ devices are shown in Figure 9(a) and Figure 9(b), respectively. In Figure 9, previously reported values [4] [21] [40] [41] and energy gaps of PMPS:B and DPPS:B estimated from the absorption spectra shown in Figure 2 were used for the energy levels. In Figure 9(a), although the lowest unoccupied molecular orbital (LUMO) energy level of PMPS was assumed approximately $-2.0 \mathrm{eV}$ [41], an energy level shift of LUMO by B doping would be conceivable [42]. In Figure 9(b), it is assumed that the LUMO of DPPS is close to that of poly(di-n-butylsilane) of -1.7 $\mathrm{eV}$ [43] because the LUMO of DPPS has not yet experimentally and theoretically been investigated. By B doping into DPPS, energy levels of DPPS would be shifted. The charge generation occurs in the $\mathrm{CH}_{3} \mathrm{NH}_{3} \mathrm{PbI}_{3}$ layer by light irradiation from the FTO bottom side. Electrons in the conduction band of $\mathrm{CH}_{3} \mathrm{NH}_{3} \mathrm{PbI}_{3}$ layer are transferred to FTO anode through $\mathrm{TiO}_{2}$. Simultaneously, holes in the valence band of $\mathrm{CH}_{3} \mathrm{NH}_{3} \mathrm{PbI}_{3}$ are transported to $\mathrm{Au}$ cathode through the polysilanes. Compared to $\mathrm{CH}_{3} \mathrm{NH}_{3} \mathrm{PbI}_{3}$-based photovoltaic device with PMPS:B layer, it is considered that an effective hole transport occurred from the valence band of $\mathrm{CH}_{3} \mathrm{NH}_{3} \mathrm{PbI}_{3}$ to $\mathrm{Au}$ cathode through the DPPS:B in the $\mathrm{CH}_{3} \mathrm{NH}_{3} \mathrm{PbI}_{3}$-based one, which was due to proper Si content and molecular structures of the DPPS:B. Furthermore, a heat treatment-like effect was caused for the DPPS:B layer during Au evaporation, which likely to lead to crystallization and increase in mobility of DPPS:B layer.

Finally, composition ratio of $\mathrm{Pb}$ and I atoms presented in Table 2 is very sensitive to photovoltaic performance. Compared with photovoltaic devices fabricated without air blow-assisted spin-coating method [25] [29] [30], the

(a)

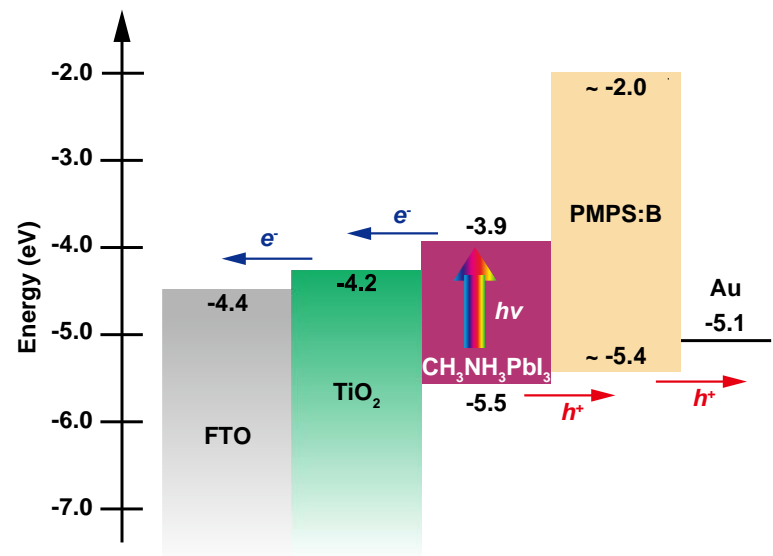

(b)

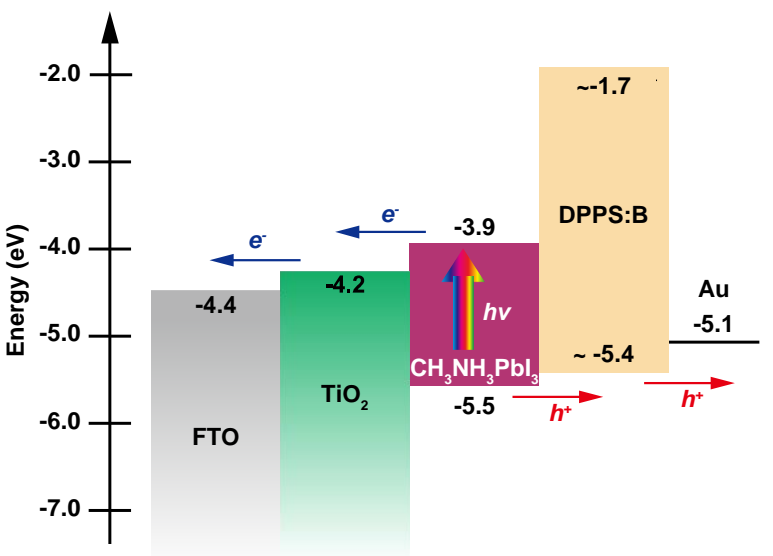

Figure 9. Energy band diagrams of (a) $\mathrm{FTO} / \mathrm{TiO}_{2} / \mathrm{CH}_{3} \mathrm{NH}_{3} \mathrm{PbI}_{3} / \mathrm{PMPS}: \mathrm{B} / \mathrm{Au}$ and (b) $\mathrm{FTO} / \mathrm{TiO}_{2} / \mathrm{CH}_{3} \mathrm{NH}_{3} \mathrm{PbI} / \mathrm{DPPS}: \mathrm{B} / \mathrm{Au}$ devices. 
present $\mathrm{CH}_{3} \mathrm{NH}_{3} \mathrm{PbI}_{3}$ layers were $\mathrm{Pb}$-rich and I-poor, suggesting that the $\mathrm{CH}_{3} \mathrm{NH}_{3} \mathrm{PbI}_{3}$ layers were $n$-type. Types of conductivity of perovskite compounds strongly depend on composition ratio of themselves. In fact, Wang et al. reported that $\mathrm{PbI}_{2}$-rich $\mathrm{CH}_{3} \mathrm{NH}_{3} \mathrm{PbI}_{3}$ behaved like an $n$-type semiconductor [44]. To improve the photovoltaic performance of perovskite-type solar cells with polysilane hole transport layers, investigation of electrical, optical and photovoltaic properties of polysilanes including $p$-type dopants should be necessary.

\section{Conclusion}

Perovskite-type photovoltaic devices with polysilane hole transport layers were fabricated and were investigated. As-deposited PMPS:B and DPPS:B layers were amorphous, and their optical absorption spectra showed some marked features originated from transitions. $J-V$ characteristics of the $\mathrm{CH}_{3} \mathrm{NH}_{3} \mathrm{PbI}_{3}$-based photovoltaic devices with PMPS:B and DPPS:B layers exhibited different photovoltaic performance each other. Conversion efficiency of the $\mathrm{CH}_{3} \mathrm{NH}_{3} \mathrm{PbI}_{3}$-based photovoltaic device with DPPS:B layer was slightly higher than that with PMPS:B one. These results were attributed to molecular structures of polysilanes and Si content in the polysilane hole transport layers of the present devices. In order to realize inexpensive perovskite-type solar cells with polysilane hole transport layers, further investigation of polysilanes, including electrical, optical and photovoltaic properties, and optimization of dopants and their concentration would be required.

\section{Acknowledgements}

This work was partly supported by Super Cluster Program of Japan Science and Technology Agency (JST) and JSPS KAKENHI Grant Number 25420760.

\section{References}

[1] Kojima, A., Teshima, K., Shirai, Y. and Miyasaka, T. (2009) Organometal Halide Perovskites as Visible-Light Sensitizers for Photovoltaic Cells. Journal of the American Chemical Society, 131, 6050-6051. https://doi.org/10.1021/ja809598r

[2] Im, J.-H., Lee, C.-R., Lee, J.-W., Park, S.-W. and Park, N.-G. (2011) 6.5\% Efficient Perovskite Quantum-Dot-Sensitized Solar Cell. Nanoscale, 3, 4088-4093. https://doi.org/10.1039/c1nr10867k

[3] Kim, H.-S., Lee, C.-R., Im, J.-H., Lee, K.-B., Moehl, T., Marchioro, A., Moon, S.-J., Humphry-Baker, R., Yum, J.-H., Moser, J.E., Grätzel, M. and Park, N.G. (2012) Lead Iodide Perovskite Sensitized All-Solid-State Submicron Thin Film Mesoscopic Solar Cell with Efficiency Exceeding 9\%. Scientific Reports, 2, 591. https://doi.org/10.1038/srep00591

[4] Noh, J.H., Im, S.H., Heo, J.H., Mandal, T.N. and Seok, S.I. (2013) Chemical Management for Colorful, Efficient, and Stable Inorganic-Organic Hybrid Nanostructured Solar Cells. Nano Letters, 13, 1764-1769. https://doi.org/10.1021/nl400349b

[5] Burschka, J., Pellet, N., Moon, S.-J., Humphry-Baker, R., Gao, P., Nazeerudin, M.K. and Grätzel, M. (2013) Sequential Deposition as a Route to High-Performance Perovskite-Sensitized Solar Cells. Nature, 499, 316-319.

https://doi.org/10.1038/nature12340 
[6] Yang, W.S., Nor, J.H., Jeon, N.J., Kim, Y.C., Ryu, S., Seo, J. and Seok, S.I. (2015) High-Performance Photovoltaic Perovskite Layers Fabricated through Intramolecular Exchange. Science, 348, 1234-1237. https://doi.org/10.1126/science.aaa9272

[7] McMeekin, D.P., Sadoughi, G., Rehman, W., Eperon, E., Saliba, M., Horantner, M.T., Haghighirad, A., Sakai, N., Korte, L., Rech, B., Johnston, M.B., Herz, L.M. and Snaith, H.J. (2016) A Mixed-Cation Lead Mixed-Halide Perovskite Absorber for Tandem Solar Cells. Science, 351, 151-155. https://doi.org/10.1126/science.aad5845

[8] Bi, D., Tress, W., Dar, M.I., Gao, P., Luo, J., Renevier, C., Schenk, K., Abate, A., Giordano, F., Correa-Baena, J.-P., Decoppet, J.-D., Zakeeruddin, S.M., Nazeeruddin, M.K., Grätzel, M. and Hagfeldt, A. (2016) Efficient Luminescent Solar Cells Based on Tailored Mixed-Cation Perovskites. Science Advances, 2, Article ID: e1501170. https://doi.org/10.1126/sciadv.1501170

[9] Saliba, M., Matsui, T., Seo, J.-Y., Domanski, K., Correa-Baena, J.-P., Nazeeruddin, M.K., Zakeeruddin, S.M., Tress, W., Abate, A., Hagfeldt, A. and Grätzel, M. (2016) Cesium-Containing Triple Cation Perovskite Solar Cells: Improved Stability, Reproducibility and High Efficiency. Energy and Environmental Science, 9, 1989-1997. https://doi.org/10.1039/C5EE03874J

[10] Saliba, M., Orlandi, S., Matsui, T., Aghazada, S., Cavazzini, M., Correa-Baena, J.-P., Gao, P., Scopelliti, R., Mosconi, E., Dahmen, K.-H., De Angelis, F., Abate, A., Hagfeldt, A., Pozzi, G., Grätzel, M. and Nazeeruddin, M.K. (2016) A Molecularly Engineered Hole-Transporting Material for Efficient Perovskite Solar Cells. Nature Energy, 1, Article ID: 15017. https://doi.org/10.1038/nenergy.2015.17

[11] Yi, C., Li, X., Luo, J., Zakeeruddin, S.M. and Grätzel, M. (2016) Perovskite Photovoltaics with Outstanding Performance Produced by Chemical Conversion of Bilayer Mesostructured Lead Halide/TiO 2 Films. Advanced Materials, 28, 2964-2970. https://doi.org/10.1002/adma.201506049

[12] Bi, D., Yi, C., Luo, J., Decoppet, J.-D., Zhang, F., Zakeeruddin, S.M., Li, X., Hagfeldt, A. and Grätzel, M. (2016) Polymer-Templated Nucleation and Crystal Growth of Perovskite Films for Solar Cells with Efficiency Greater than 21\%. Nature Energy, 1, Article ID: 16142. https://doi.org/10.1038/nenergy.2016.142

[13] Chart of Best Research-Cell Efficiencies Provided by NREL. http://www.nrel.gov/pv/assets/images/efficiency_chart.jpg

[14] Zhao, X. and Park, N.-G. (2015) Stability Issues on Perovskite Solar Cells. Photonics, 2, 1139-1151. https://doi.org/10.3390/photonics2041139

[15] Kumar, C.V., Sfyri, G., Raptis, D., Stathatos, E. and Lianos, P. (2015) Perovskite Solar Cell with Low Cost Cu-Phthalocyanine as Hole Transporting Material. RSC Advances, 5, 3786-3791. https://doi.org/10.1039/C4RA14321C

[16] Qin, P., Tanaka, S., Ito, S., Tetreault, N., Manabe, K., Nishino, H., Nazeeruddin, M.K. and Grätzel, M. (2014) Inorganic Hole Conductor-Based Lead Halide Perovskite Solar Cells with 12.4\% Conversion Efficiency. Nature Communications, 5, 3834. https://doi.org/10.1038/ncomms4834

[17] Ito, S., Tanaka, S., Vahlman, H., Nishino, H., Manabe, K. and Lund, P. (2014) Carbon-Double-Bond-Free Printed Solar Cells from $\mathrm{TiO}_{2} / \mathrm{CH}_{3} \mathrm{NH}_{3} \mathrm{PbI}_{3} / \mathrm{CuSCN} / \mathrm{Au}$ : Structural Control and Photoaging Effects. ChemPhysChem, 15, 1194-1200. https://doi.org/10.1002/cphc.201301047

[18] Suzuki, A., Kida, T., Takagi, T. and Oku, T. (2016) Effects of Hole-Transporting Layers of Perovskite-Based Solar Cells. Japanese Journal of Applied Physics, 55, 02BF01. https://doi.org/10.7567/jjap.55.02bf01

[19] Kepler, R.G. (1989) Electronic Properties of $\sigma$-Conjugated Polysilanes. Synthetic Metals, 28, 573-580. https://doi.org/10.1016/0379-6779(89)90576-6 
[20] Furukawa, K., Fujino, M. and Matsumoto, N. (1990) Optical Properties of Silicon Network Polymers. Macromolecules, 23, 3423-3426. https://doi.org/10.1021/ma00216a006

[21] Haga, Y. and Harada, Y. (2001) Photovoltaic Characteristics of Phtaalocyanine-Polysilane Composite Films. Japanese Journal of Applied Physics, 40, 855-861. https://doi.org/10.1143/JJAP.40.855

[22] Oku, T., Nakagawa, J., Iwase, M., Kawashima, A., Yoshida, K., Suzuki, A., Akiyama, T., Tokumitsu, K., Yamada, M. and Nakamura, M. (2013) Microstructures and Photovoltaic Properties of Polysilane-Based Solar Cells. Japanese Journal of Applied Physics, 52, 04CR07. https://doi.org/10.7567/jjap.52.04cr07

[23] Iwase, M., Oku, T., Suzuki, A., Akiyama, T., Tokumitsu, K., Yamada, M. and Nakamura, M. (2012) Fabrication and Characterization of Poly[Diphenylsilane]-Based Solar Cells. Journal of Physics: Conference Series, 352, Article ID: 012018. https://doi.org/10.1088/1742-6596/352/1/012018

[24] Nakagawa, J., Oku, T., Suzuki, A., Akiyama, T., Tokumitsu, K., Yamada, M. and Nakamura, M. (2012) Fabrication and Characterization of Polysilane/ $\mathrm{C}_{60}$ Thin Film Solar Cells. Journal of Physics. Conference Series, 352, Article ID: 012019. https://doi.org/10.1088/1742-6596/352/1/012019

[25] Shirahata, Y., Yamamoto, Y., Suzuki, A., Oku, T., Fukunishi, S. and Kohno, K. (2016) Effects of Polysilane-Doped Spiro-OMeTAD Hole Transport Layers on Photovoltaic Properties. Physica Status Solidi A. https://doi.org/10.1002/pssa.201600591

[26] Oku, T., Hibi, N., Suzuki, A., Akiyama, T., Yamada, M., Fukunishi, S. and Kohno, K. (2015) Effects of Triphenylborane Addition to Decaphenylcyclopentasilane Thin Films. JJAP Conference Proceedings, 3, Article ID: 011404. https://doi.org/10.7567/jjapcp.3.011404

[27] Oku, T., Zushi, M., Imanishi, Y., Suzuki, A. and Suzuki, K. (2014) Microstructures and Photovoltaic Properties of Perovskite-Type $\mathrm{CH}_{3} \mathrm{NH}_{3} \mathrm{PbI}_{3}$ Compounds. Applied Physics Express, 7, Article ID: 121601. https://doi.org/10.7567/apex.7.121601

[28] Oku, T., Ohishi, Y. and Suzuki, A. (2016) Effects of Antimony Addition to Perovskite-Type $\mathrm{CH}_{3} \mathrm{NH}_{3} \mathrm{PbI}_{3}$ Photovoltaic Devices. Chemistry Letters, 45, 134-136. https://doi.org/10.1246/cl.150984

[29] Oku, T., Ohishi, Y., Suzuki, A. and Miyazawa, Y. (2016) Effects of Cl Addition to Sb-Doped Perovskite-Type $\mathrm{CH}_{3} \mathrm{NH}_{3} \mathrm{PbI}_{3}$ Photovoltaic Devices. Metals, 6, 147. https://doi.org/10.3390/met6070147

[30] Suzuki, A., Okada, H. and Oku, T. (2016) Fabrication and Characterization of $\mathrm{CH}_{3} \mathrm{NH}_{3} \mathrm{PbI}_{3-\mathrm{x}-\mathrm{y}} \mathrm{Br}_{\mathrm{x}} \mathrm{Cl}_{\mathrm{y}}$ Perovskite Solar Cells. Energies, 9, 346. https://doi.org/10.3390/en9050376

[31] Shirahata, Y., Suzuki, A. and Oku, T. (2016) Fabrication and Characterization of Bismuth Ferrite as an Electron Transport Layer in Perovskite Photovoltaic Devices. Journal of the Ceramics Society of Japan, 124, 602-605. https://doi.org/10.2109/jcersj2.15322

[32] Eze, V.O., Lei, B. and Mori, T. (2016) Air-Assisted Flow and Two-Step Spin-Coating for Highly Efficient $\mathrm{CH}_{3} \mathrm{NH}_{3} \mathrm{PbI}_{3}$ Perovskite Solar Cells. Japanese Journal of Applied Physics, 55, 02BF08. https://doi.org/10.7567/JJAP.55.02BF08

[33] Kim, H.-B., Choi, H., Jeong, J., Kim, S., Walker, B., Song, S. and Kim, J.Y. (2014) Mixed Solvents for the Optimization of Morphology in Solution-Processed, Inverted-Type Perovskite/Fullerene Hybrid Solar Cells. Nanoscale, 6, 6679-6683. https://doi.org/10.1039/c4nr00130c

[34] Tachibana, H., Mizuno, T. and Ishibe, S. (2011) Optical Properties of Siloxene Films 
Prepared by High-Temperature Heat Treatment from Thin Films of Polysilane Containing Anthryl Groups. Japanese Journal of Applied Physics, 50, $04 \mathrm{DK} 18$. https://doi.org/10.1143/JJAP.50.04DK18

[35] Nešpůrek, S., Schauer, F. and Kadashchuk, A. (2001) Visible Photoluminescence in Polysilanes. Monatshefte für Chemie Chemical Monthly, 132, 159-168. https://doi.org/10.1007/s007060170155

[36] Ouyang, W., Kuna, E., Yepez, A., Balu, A.M., Romero, A.A., Colmenares, J.C. and Luque, R. (2016) Mechanochemical Synthesis of $\mathrm{TiO}_{2}$ Nanocomposites as Photocatalysts for Benzyl Alcohol Photo-Oxidation. Nanomaterials, 6, 93. https://doi.org/10.3390/nano6050093

[37] Song, Z., Watthage, S.C., Phillips, A.B., Tompkins, B.L., Ellingson, R.J. and Heben, M.J. (2015) Impact of Processing Temperature and Composition on the Formation of Methylammonium Lead Iodide Perovskites. Chemistry of Materials, 27, 4612 4619. https://doi.org/10.1021/acs.chemmater.5b01017

[38] Yamada, Y., Nakamura, T., Endo, M., Wakamiya, A. and Kanemitsu, Y. (2014) Near-Band-Edge Optical Responses of Solution-Processed Organic-Inorganic Hybrid Perovskite $\mathrm{CH}_{3} \mathrm{NH}_{3} \mathrm{PbI}_{3}$ on Mesoporous $\mathrm{TiO}_{2}$ Electrodes. Applied Physics EXpress, 7, Article ID: 032302. https://doi.org/10.7567/APEX.7.032302

[39] Leong, W.L., Ooi, Z.-E., Sabba, D., Yi, C., Zakeeruddin, S.M., Grätzel, M., Gordan, J.M., Katz, E.A. and Mathews, N. (2016) Identifying Fundamental Limitations in Halide Perovskite Solar Cells. Advanced Materials, 28, 2439-2445.

https://doi.org/10.1002/adma.201505480

[40] Ogomi, Y., Morita, A., Tsukamoto, S., Saitho, T., Fujikawa, N., Shen, Q., Toyoda, T., Yoshino, K., Pandey, S.S., Ma, T. and Hayase, S. (2014) $\mathrm{CH}_{3} \mathrm{NH}_{3} \mathrm{Sn}_{x} \mathrm{~Pb}_{(1-x)} \mathrm{I}_{3}$ Perovskite Solar Cells Covering up to $1060 \mathrm{~nm}$. Journal of Physical Chemistry Letters, 5, 1004-1011. https://doi.org/10.1021/jz5002117

[41] Green, M.A., Ho-Baillie, A. and Snaith, H.J. (2014) The Emergence of Perovskite Solar Cells. Nature Photonics, 8, 506-514. https://doi.org/10.1038/nphoton.2014.134

[42] Kim, J.Y., Kim, S.H., Lee, H.-H., Lee, K., Ma, W., Gong, X. and Heeger, A.J. (2006) New Architecture for High-Efficiency Polymer Photovoltaic Cells Using SolutionBased Titanium Oxide as an Optical Spacer. Advanced Materials, 18, 572-576. https://doi.org/10.1002/adma.200501825

[43] Isaka, H. and Matsumoto, N. (1990) One-Dimensional Hetero-Junction Structure in Polysilane. Journal of Applied Physics, 68, 6380-6382. https://doi.org/10.1063/1.346885

[44] Wang, Q., Shao, Y., Xie, H., Lyu, L., Liu, X., Gao, Y. and Huang, J. (2014) Qualifying Composition Dependent $p$ and $n$ Self-Doping in $\mathrm{CH}_{3} \mathrm{NH}_{3} \mathrm{PbI}_{3}$. Applied Physics Letters, 105, Article ID: 163508. https://doi.org/10.1063/1.4899051 
Submit or recommend next manuscript to SCIRP and we will provide best service for you:

Accepting pre-submission inquiries through Email, Facebook, LinkedIn, Twitter, etc. A wide selection of journals (inclusive of 9 subjects, more than 200 journals)

Providing 24-hour high-quality service

User-friendly online submission system

Fair and swift peer-review system

Efficient typesetting and proofreading procedure

Display of the result of downloads and visits, as well as the number of cited articles Maximum dissemination of your research work

Submit your manuscript at: http://papersubmission.scirp.org/

Or contact msa@scirp.org 